\title{
Transient Receptor Potential Channel Ankyrin-1 Is Not a Cold Sensor for Autonomic Thermoregulation in Rodents
}

\author{
Cristiane de Oliveira, ${ }^{1 \star}$ Andras Garami, ${ }^{1,2 \star}$ Sonya G. Lehto, ${ }^{3}$ Eszter Pakai, ${ }^{2}$ Valeria Tekus, ${ }^{4,5}$ Krisztina Pohoczky, ${ }^{4}$ \\ Beth D. Youngblood, ${ }^{3}$ Weiya Wang, ${ }^{3}$ Michael E. Kort, ${ }^{6}$ Philip R. Kym, ${ }^{6}$ Erika Pinter, ${ }^{4,5}$ Narender R. Gavva, ${ }^{3}$ \\ and Andrej A. Romanovsky ${ }^{1}$ \\ ${ }^{1}$ Systemic Inflammation Laboratory (FeverLab), Trauma Research, St. Joseph's Hospital and Medical Center, Phoenix, Arizona 85013, ${ }^{2}$ Department of \\ Pathophysiology and Gerontology, Medical School, University of Pecs, Pecs, H-7624, Hungary, ${ }^{3}$ Department of Neuroscience, Amgen Inc., Thousand Oaks, \\ California 91320, ${ }^{4}$ Department of Pharmacology and Pharmacotherapy, Medical School, University of Pecs, Pecs, H-7624, Hungary, 5 Janos Szentagothai \\ Research Centre, University of Pecs, Pecs, H-7624, Hungary, and 'Neuroscience Research, Global Pharmaceutical Research and Development, AbbVie Inc., \\ North Chicago, Illinois 60064
}

The rodent transient receptor potential ankyrin-1 (TRPA1) channel has been hypothesized to serve as a temperature sensor for thermoregulation in the cold. We tested this hypothesis by using deletion of the Trpal gene in mice and pharmacological blockade of the TRPA1 channel in rats. In both $\operatorname{Trpa1}^{-1-}$ and Trpa $1^{+/+}$mice, severe cold exposure $\left(8^{\circ} \mathrm{C}\right)$ resulted in decreases of skin and deep body temperatures to $\sim 8^{\circ} \mathrm{C}$ and $13^{\circ} \mathrm{C}$, respectively, both temperatures being below the reported $17^{\circ} \mathrm{C}$ threshold temperature for TRPAl activation. Under these conditions, Trpa1 ${ }^{-1-}$ mice had the same dynamics of body temperature as Trpa1 ${ }^{+/+}$mice and showed no weakness in the tail skin vasoconstriction response or thermogenic response to cold. In rats, the effects of pharmacological blockade were studied by using two chemically unrelated TRPA1 antagonists: the highly potent and selective compound A967079, which had been characterized earlier, and the relatively new compound $43((4 R)-1,2,3,4$-tetrahydro-4-[3-(3-methoxypropoxy)phenyl]-2-thioxo-5H-indeno[1,2d]pyrimidin-5-one), which we further characterized in the present study and found to be highly potent $\left(\mathrm{IC}_{50}\right.$ against cold of $\left.\sim 8 \mathrm{nM}\right)$ and selective. Intragastric administration of either antagonist at $30 \mathrm{mg} / \mathrm{kg}$ before severe $\left(3^{\circ} \mathrm{C}\right)$ cold exposure did not affect the thermoregulatory responses (deep body and tail skin temperatures) of rats, even though plasma concentrations of both antagonists well exceeded their $\mathrm{IC}_{50}$ value at the end of the experiment. In the same experimental setup, blocking the melastatin-8 (TRPM8) channel with AMG2850 $(30 \mathrm{mg} / \mathrm{kg})$ attenuated cold-defense mechanisms and led to hypothermia. We conclude that TRPA1 channels do not drive autonomic thermoregulatory responses to cold in rodents.

Key words: cold exposure; hypothermia; thermoregulation; TRPA1; TRPM8

\section{Introduction}

Among transient receptor potential (TRP) channels, the cation channel TRP ankyrin-1 (TRPA1, formerly known as ANKTM1)

Received Dec. 24, 2013; revised Jan. 31, 2014; accepted Feb. 7, 2014.

Author contributions: C.d.O., A.G., S.G.L., M.E.K., P.R.K., E. Pinter, N.R.G., and A.A.R. designed research; C.d.0., A.G., S.G.L., E. Pakai, V.T., K.P., B.D.Y., and W.W. performed research; P.R.K., E. Pinter, and N.R.G. contributed unpublished reagents/analytic tools; C.d.O., A.G., S.G.L., V.T., B.D.Y., W.W., M.E.K., P.R.K., E. Pinter, N.R.G., and A.A.R. analyzed data; C.d.O., A.G., and A.A.R. wrote the paper.

This work was supported in part by the National Institutes of Health Grant R01NS41233 to A.A.R., the Hungarian Scientific Research Fund Grant PD105532 to A.G. and Grant K81984 to E. Pinter, and the Janos Bolyai Research Scholarship of the Hungarian Academy of Sciences to A.G. The authors thank Dr. Pierangelo Geppetti for donating Trpa $1^{+/-}$mice; Drs. Stephanie Guens-Meyer and Qian Wan for synthesizing compounds 43 and 44; and Joshua J. Corrigan for editing the manuscript.

S.G.L., B.D.Y., W.W. and N.R.G. are employed by Amgen Inc. M.E.K. and P.R.K. are employed by AbbVie Inc. A.A.R. has consulted for TRP programs at Amgen Inc., Abbott Laboratories, and several other pharmaceutical companies, and his TRP-related research has been supported by Amgen Inc., Abbott Laboratories, and AbbVie Inc. The remaining authors declare no competing financial interests.

${ }^{*}$ C.d.O. and A.G. contributed equally to this work.

This article is freely available online through the J Neurosci Author Open Choice option.

Correspondence should be addressed to Dr. Andrej A. Romanovsky, FeverLab, St. Joseph's Hospital, 350 W. Thomas Road, Phoenix, AZ 85013. E-mail: andrej.romanovsky@dignityhealth.org.

DOI:10.1523/JNEUROSCI.5387-13.2014

Copyright $\odot 2014$ the authors $\quad 0270-6474 / 14 / 344445-08 \$ 15.00 / 0$ is unique in that, despite the tremendous amount of research, it is still not clear whether and how it is activated by temperature (Bang and Hwang, 2009; Caspani and Heppenstall, 2009; Kwan and Corey, 2009; Nilius et al., 2012). Since the first demonstration of cold sensitivity of TRPA1 by Story et al. (2003), many in vitro and in vivo studies have supported the notion that TRPA1 is involved in the sensation of noxious cold (Viswanath et al., 2003; Bandell et al., 2004; Kwan et al., 2006; Klionsky et al., 2007; Fajardo et al., 2008; Andersson et al., 2009; Karashima et al., 2009; del Camino et al., 2010). However, many other studies, both in vitro and in vivo, have contradicted this notion (Jordt et al., 2004; Nagata et al., 2005; Bautista et al., 2006, 2007; Kwan et al., 2009; Knowlton et al., 2010; del Camino et al., 2010; Chen et al., 2011; Cordero-Morales et al., 2011). Further complicating the issue, some TRPA1 orthologs (e.g., in pit-bearing snakes and insects) are activated by warmth, rather than cold (Viswanath et al., 2003; Hamada et al., 2008; Kwon et al., 2008; Gracheva et al., 2010). With some exceptions (Chen et al., 2011), most studies in mammals have focused on the role of TRPA1 in nocifensive behaviors, which is not surprising because the low threshold temperature for activation of this channel in vitro $\left(<17^{\circ} \mathrm{C}\right.$, according to Story et 
al., 2003; or somewhere between $11^{\circ} \mathrm{C}$ and $25^{\circ} \mathrm{C}$, according to Klionsky et al., 2007) is close to the threshold temperature for pain responses in humans (Davis and Pope, 2002).

The question of whether peripheral TRPA1 channels can serve as cold sensors for the thermoregulation system was previously touched upon in two studies (Bautista et al., 2007; Chen et al., 2011), but no definitive answer was obtained. The first study (Bautista et al., 2007) showed that deletion of the Trpal gene in mice did not lower their selected ambient temperature $\left(T_{a}\right)$, thus suggesting that TRPA1 is not involved in the control of thermopreferendum. However, these mice were not subjected to any prolonged cold exposure that might have been required for TRPA1 activation. Furthermore, deep body temperature $\left(T_{b}\right)$ was not measured in the Trpa1 $1^{-1-}$ mice; if it was decreased, signals from deep-tissue thermosensors (other than TRPA1) could have compensated for the lack of TRPA1-mediated cold signals from the skin. The second study (Chen et al., 2011) showed that A967079, a potent and selective TRPA1 antagonist, did not affect the deep $T_{b}$ in rats at near-thermoneutral conditions (i.e., at temperatures substantially higher than those required for TRPA1 activation). The effects of A967079 in the cold (when TRPA1 channels may be activated) were not investigated. In the present study, we studied the effects of genetic deletion and pharmacological blockade of TRPA1 on the deep $T_{b}$ and thermoeffector activities in mice and rats exposed to deep cold.

\section{Materials and Methods}

Animals. Breeding pairs of Trpa1 ${ }^{+/-}$mice were donated to the University of Pecs by Dr. Pierangelo Geppetti. The mice came from the University of Florence colony, which in turn originated from the colony of the University of California, San Francisco (Bautista et al., 2006). At the University of Pecs, the first-generation offsprings of the donated Trpa1 ${ }^{+/-}$mice were genotyped by PCR analysis (Knowlton et al., 2010) and bred as separate wild-type $\left(\operatorname{Trpa1}^{+/+}\right)$and homozygous genedeleted $\left(\operatorname{Trpa1}^{-1-}\right)$ lines. Fourteen mice of both sexes representing the first two generations of each line were used in Experiment 1 (also at the University of Pecs). At the time of experiments, the mice weighed 22-27 g. Forty male Sprague Dawley rats (Harlan) weighing 220-300 g were housed and used in Experiment 2 at Amgen. Sixty male Wistar rats (Harlan) weighing 150-250 g were housed and used in Experiment 3 at St. Joseph's Hospital and Medical Center. At all three centers, animals were housed in temperature-controlled rooms on a 12/12 h light/dark cycle. Standard rodent chow and tap water were available ad libitum. For thermophysiological experiments (Experiments 1 and 3), mice and rats were extensively habituated to staying inside wire-mesh cylindrical confiners as described previously (Romanovsky et al., 2002; Garami et al., 2011). All procedures conducted at each center were approved by the Institutional Animal Use and Care Committee of the University of Pecs, Amgen, or St. Joseph's Hospital and Medical Center, respectively.

Drugs. The TRPA1 antagonist compound $43((4 R)-1,2,3,4$-tetrahydro4-[3-(3-methoxypropoxy)phenyl]-2-thioxo-5H-indeno[1,2- $d$ ] pyrimidin5 -one) and its inactive (left) enantiomer compound 44 were synthesized by Amgen as enantiopure compounds using the Gijsen et al. (2012) method with modifications. The TRPA1 antagonist A967079 ((1E,3E)1-(4-fluorophenyl)-2-methylpent-1-en-3-one oxime), reported by Chen et al. (2011), was synthesized by AbbVie. The TRP melastatin-8 (TRPM8) channel antagonist AMG2850 ((R)-8-[4-(trifluoromethyl)phenyl]$N$-[( S)-1,1,1-trifluoropropan-2-yl]-5,6-dihydro-1,7-naphthyridine7-(8H)-carboxamide), recently reported by Gavva et al. (2012), was synthesized by Amgen. For intragastric (i.g.) gavage, all compounds were suspended in the vehicle (Amgen) containing 2\% HPMC and 1\% Tween 80 at $\mathrm{pH} 2.2$ (adjusted with methanesulfonic acid). The vehicle or suspension of compound $43(1-10 \mathrm{mg} / \mathrm{ml})$, compound $44(10 \mathrm{mg} / \mathrm{ml})$, A967079 (3 mg/ml), or AMG2850 (3 mg/ml) was administered (10 ml/ $\mathrm{kg}$, i.g.) using disposable soft feeding needles. The doses delivered were as follows: $10-100 \mathrm{mg} / \mathrm{kg}$ (compound 43), $100 \mathrm{mg} / \mathrm{kg}$ (compound 44), 30 $\mathrm{mg} / \mathrm{kg}$ (A967079), and $30 \mathrm{mg} / \mathrm{kg}$ (AMG2850).

$\mathrm{Ca}^{2+}$ uptake. Chinese hamster oocyte lines expressing rat TRPA1 were generated in tetracycline-inducible TREx expression system (Invitrogen) (Klionsky et al., 2007). Cells $\left(3.0 \times 10^{4}\right.$ per well) were seeded in Cytostar 96-well plates (PerkinElmer) and exposed to tetracycline $(0.5 \mu \mathrm{g} / \mathrm{ml})$. One day later, allyl isothiocyanate (AITC)- or cold-induced TRPA1 activation was measured as cellular uptake of ${ }^{45} \mathrm{Ca}^{2+}$ (PerkinElmer). For the response to AITC, the culture media was aspirated, and the cells were incubated with compound 43 or 44 in the assay buffer (F-12 medium supplemented with BSA, $0.1 \mathrm{mg} / \mathrm{ml}$, and $15 \mathrm{~mm}$ HEPES) at room temperature for $3 \mathrm{~min}$ before and $3 \mathrm{~min}$ after the addition of AITC at $\mathrm{EC}_{90}$ $(80 \mu \mathrm{M})$. To measure the response to cold, cells were incubated with compound 43 or 44 in the assay buffer for $3 \mathrm{~min}$ at room temperature. Thereafter, ${ }^{45} \mathrm{Ca}^{2+}$ was added, and the plates were left on an EchoTherm chilling platform (Torrey Pines) for $12 \mathrm{~min}$ to reach the temperature of $7^{\circ} \mathrm{C}$. The plates were washed twice with PBS, and the results were read on TopCount. Compound activity was analyzed using Prism 4.01 (GraphPad Software).

Nocifensive response in mice. Before experiments, mice were habituated to the experimental conditions for $1 \mathrm{~h}$. Mustard oil $(0.75 \%, 20 \mu \mathrm{l})$, which is often used to assess TRPA1-mediated pain (Jordt et al., 2004; Bautista et al., 2006; Kwan et al., 2006), was injected into the right hindpaw. Paw-licking and lifting events were timed for $5 \mathrm{~min}$ by an observer blind to the animals' genotype.

Nocifensive response in rats. Before experiments, rats were habituated to the experimental room (30 $\mathrm{min})$ and to Plexiglas observation cylinders (additional $30 \mathrm{~min}$ ). The cylinders were placed on a custom apparatus in a way that rats could not see each other. Compound $43(10,30$, or 100 $\mathrm{mg} / \mathrm{kg})$, compound $44(100 \mathrm{mg} / \mathrm{kg})$, or their vehicle was administered by gastric gavage $1 \mathrm{~h}$ before the injection of AITC $(0.01 \%, 25 \mu \mathrm{l})$ into the left hindpaw. The AITC dose was chosen based on an in-house (Amgen) dose-response curve and corresponded to a dose between $\mathrm{ED}_{50}$ and $\mathrm{ED}_{80}$. The number of hindpaw flinches was counted for $1 \mathrm{~min}$ by an observer blind to the experimental treatment.

Cold-defense responses in mice. Each mouse was placed in a confiner and equipped with copper-constantan thermocouples (Omega Engineering) to measure colonic $T_{b}$ and tail skin temperature $\left(T_{s k}\right)$. The colonic thermocouple was introduced $2 \mathrm{~cm}$ beyond the anal sphincter and secured in the base of the tail with adhesive tape. The skin thermocouple was fixed to the lateral surface of the tail at the borderline between the proximal and middle thirds with a loop of tape, which also insulated the thermocouple from the environment. A similar method was used to record thermoregulatory responses of mice to cold in our recent study (Garami et al., 2011). The mouse in its confiner was transferred to a Plexiglas chamber of the four-chamber open-circuit calorimeter integrated system (Oxymax Equal Flow, Columbus Instruments). The chamber was sealed, submerged into a temperature-controlled $\left(30^{\circ} \mathrm{C}\right)$ water bath, and continuously ventilated with room air $(200 \mathrm{ml} / \mathrm{min})$. The fractional concentration of oxygen was measured in the air entering and exiting the chamber, and the rate of oxygen consumption was calculated according to the manufacturer's instructions using the Oxymax Windows software (version 3.1). Cold exposure was achieved by transferring the chamber from the $30^{\circ} \mathrm{C}$ water bath to an $8^{\circ} \mathrm{C}$ water bath.

Cold-defense responses in rats. On the day of the experiment, rats in their home cages were placed inside a climatic chamber (model 3940, Forma Scientific) set to a neutral $T_{a}$ of $28^{\circ} \mathrm{C}$ (Romanovsky et al., 2002). The animals were allowed to habituate to the experimental conditions for $1 \mathrm{~h}$. Thereafter, the $T_{a}$ in the chamber was increased to $30^{\circ} \mathrm{C}$, which is in the upper portion of the thermoneutral zone in this setup (warm environment); under these conditions, tail skin is vasodilated (Romanovsky et al., 2002). Compound 43, A967079, or AMG2850 (each at $30 \mathrm{mg} / \mathrm{kg}$ ) or their vehicle was administered as gastric gavage $(10 \mathrm{ml} / \mathrm{kg})$ using disposable soft feeding needles. Each rat was then placed in a confiner and equipped with copper-constantan thermocouples (Omega Engineering) to measure deep $T_{b}$ (colonic) and tail $T_{s k}$. As in other studies from our laboratory (Steiner et al., 2007; Steiner et al., 2011; Almeida et al., 2012), the colonic thermocouple was inserted $10 \mathrm{~cm}$ beyond the anal sphincter and fixed to the base of the tail with a loop of adhesive tape. The skin 
thermocouple was positioned on the lateral surface of the tail (at the boundary of the proximal and middle thirds) and insulated from the environment with tape. Thermocouples were plugged into a data logger (Cole-Parmer). The rats in their confiners were returned to the $30^{\circ} \mathrm{C}$ chamber and left there for $30 \mathrm{~min}$ to allow the administered compound to circulate through the skin (Almeida et al., 2012). Thereafter, the rats in their confiners were transferred to another chamber set to either $3^{\circ} \mathrm{C}$ (cold exposure) or $30^{\circ} \mathrm{C}$ (control).

Plasma concentrations of compound 43 and A967079. At the end of the cold-defense test in rats, their exposure to TRPA1 antagonists was verified. Those rats that were treated with compound 43, A967079, or their vehicle were anesthetized with ketamine-xylazine-acepromazine mixture (55.6, 5.5, and $1.1 \mathrm{mg} / \mathrm{kg}$, i.p.), and cardiac blood was collected in Vacutainer tubes containing lithium heparin (compound 43) or EDTA (A967079). The tubes were centrifuged $(1200 \times g, 10 \mathrm{~min})$ at $4^{\circ} \mathrm{C}$. The plasma was transferred to cryogenic vials, shipped on dry ice to Amgen (compound 43) or AbbVie (A967079), and stored at $-80^{\circ} \mathrm{C}$. Concentrations of compound 43 and A967079 were measured by sensitive LCMS/MS methods optimized for each compound according to the standard Amgen and AbbVie protocols.

Data processing and analysis. Data on colonic $T_{b}$, tail $T_{s k}$, and oxygen consumption were compared by factorial (two-way) ANOVA followed by Tukey's honestly significant difference post hoc tests, as appropriate. Numbers of flinches were compared by one-way ANOVA with Dunnett's multiple-comparisons post hoc tests. Data on the nocifensive response duration were compared by Mann-Whitney U test. Plasma concentrations for each compound measured were compared by Student's $t$ test. Statistica AX'99 (Statsoft) and Prism 5.01 (GraphPad) software were used. Data are reported as mean $\pm \mathrm{SE}$.

\section{Results}

Experiment 1: genetic deletion of Trpa1 does not attenuate cold defenses in mice

To cool mice below the $17^{\circ} \mathrm{C}$ threshold temperature for TRPA1 activation (Story et al., 2003), we used a severe cold exposure model ( $T_{a}$ of $8^{\circ} \mathrm{C}$ for $180 \mathrm{~min}$ ) (Garami et al., 2011). In this model, both $\operatorname{Trpa1}^{+/+}$and Trpa1 ${ }^{-/-}$mice developed tail skin vasoconstriction (a decrease in tail $T_{s k}$ ) and cold-induced thermogenesis (an increase in oxygen consumption), but despite these marked cold-defense responses, the deep (colonic) $T_{b}$ temperature decreased precipitously (Fig. $1 A$ ). Neither the deep $T_{b}$ response nor the thermoeffector responses differed between the genotypes. Notably, the tail $T_{s k}$ in both genotypes dropped $<17^{\circ} \mathrm{C}$ early $(\sim 10 \mathrm{~min})$ into the cold exposure. By the end of the experiment, even the colonic $T_{b}$ was $\sim 13^{\circ} \mathrm{C}$ (i.e., $4^{\circ} \mathrm{C}$ below the TRPA1 activation threshold). Functional TRPA1 deficiency of the knock-out mice used was verified by a $56 \%$ reduction in the duration of the paw licking and lifting response to intraplantar mustard oil ( $12 \pm 3 \mathrm{~s}$ vs $27 \pm 6 \mathrm{~s}$ in $\operatorname{Trpa1} 1^{+/+}$controls; $U_{(9)}=3.5$, $Z=-2.1, p=3.6 \times 10^{-2}$; Fig. $\left.1 B\right)$. In summary, the Trpa1 deletion in mice affected neither the deep $T_{b}$ response to severe cold nor the autonomic cold defenses, even though both $T_{s k}$ and deep $T_{b}$ were below the reported threshold temperature for TRPA1 activation. This finding is in agreement with studies showing that $\operatorname{Trpa1}^{-1-}$ mice have no deficit in the detection of noxious cold (Bautista et al., 2006, 2007; Kwan et al., 2009; Knowlton et al., 2010). Either TRPA1 channels are not activated by cold in mice or they are not wired to convey temperature signals to autonomic thermoeffectors, or both. A caveat to this interpretation, however, is that $\operatorname{Trpa1} 1^{-1-}$ mice could have developed chronic compensatory upregulation of other cold sensors, which, in turn, could have become functionally important in the absence of TRPA1. To avoid chronic compensation, we decided to use genetically unaltered animals and to block their TRPA1 channels acutely by a pharmacological antagonist, either

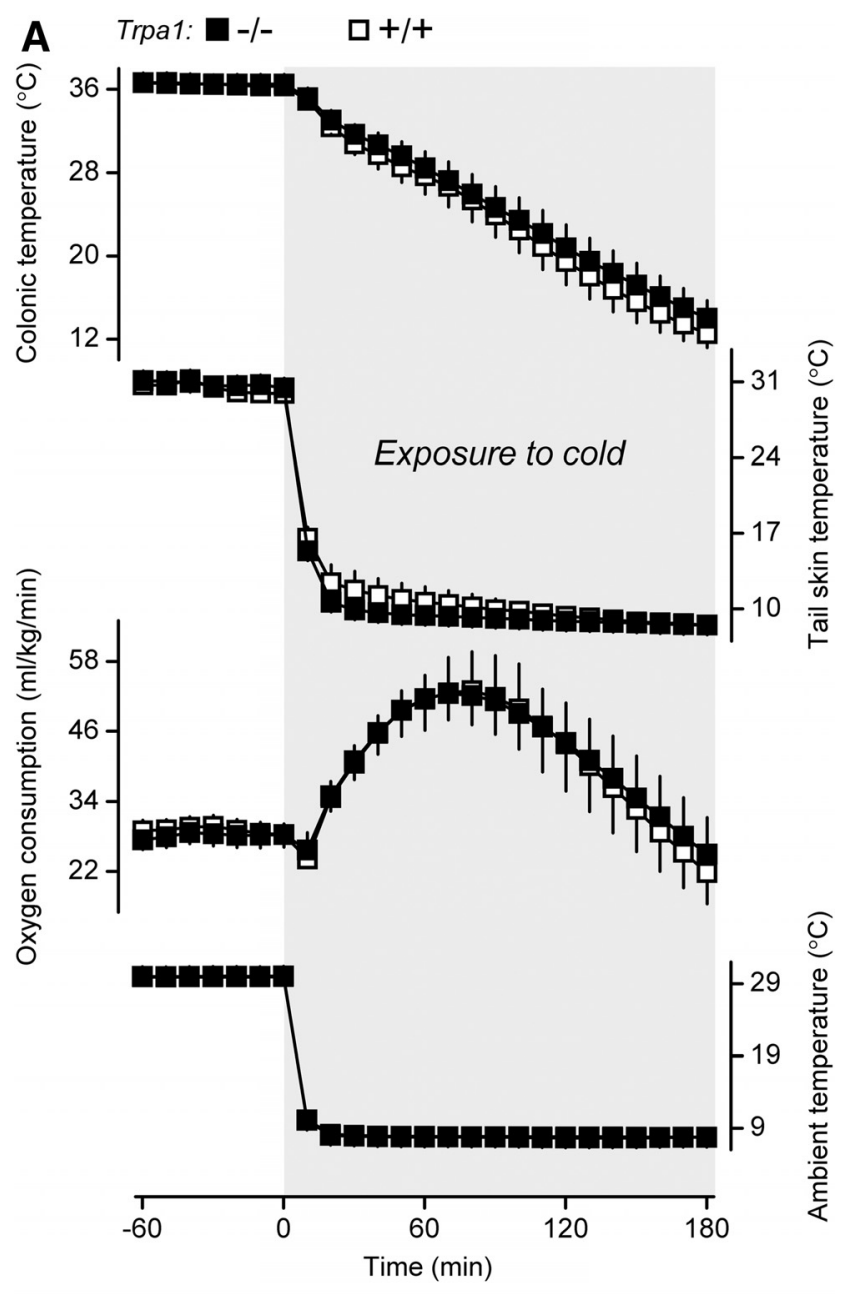

B

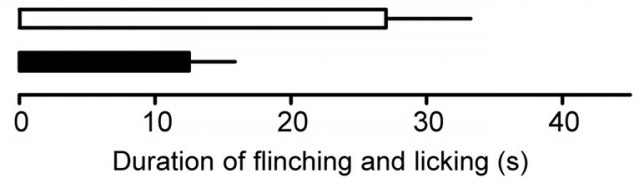

Figure 1. Cold exposure reveals no autonomic thermoregulatory deficiency in Trpa ${ }^{-1-}$ mice. $\boldsymbol{A}$, During exposure to $8^{\circ} \mathrm{C}$, there was no weakness in the defense of deep (colonic) $T_{b}$ by Trpa1 ${ }^{-1-}$ mice $(n=8)$, compared with $\operatorname{Trpa}^{+/+}$mice $(n=6)$. The $T_{b}$ dynamics did not differ between the genotypes. Both the tail skin vasoconstriction response (a decrease in the tail $T_{s k}$ ) and the thermogenic response (an increase in oxygen consumption) in $T_{r p a 1^{-1}}$ mice were no less robust than the responses in Trpa $1^{+/+}$mice. $\boldsymbol{B}$, Functional TRPA1 deficiency of $\operatorname{Trpa} 1^{-1-}$ mice $(n=6)$ compared with $\operatorname{Trpa} 1^{+/+}$mice $(n=5)$ was confirmed by a decreased pain response to intraplantar mustard oil $(0.75 \%, 20 \mu \mathrm{l})$.

A967079 (Chen et al., 2011) or compound 43 (Gijsen et al., 2012). Data on selectivity, potency, bioavailability, and efficacy of A967079 were reported by Chen et al. (2011), but only limited information about compound 43 was available (Gijsen et al., 2012).

\section{Experiment 2: compound 43 is a potent TRPA1 antagonist in} vitro and in vivo

We studied the ability of the enantiopure (right) compound 43 and its inactive (left) enantiomer, compound 44 (Gijsen et al., 2012), to block cold $\left(4^{\circ} \mathrm{C}\right)$ or chemical (AITC, $\left.80 \mu \mathrm{M}\right)$ activation of TRPA1. In Chinese hamster ovary cells transfected with rat TRPA1, compound 43 potently inhibited channel activation caused by either cold $\left(\mathrm{IC}_{50}=7.8 \pm 2.4 \mathrm{~nm}\right)$ or AITC $\left(\mathrm{IC}_{50}=\right.$ 


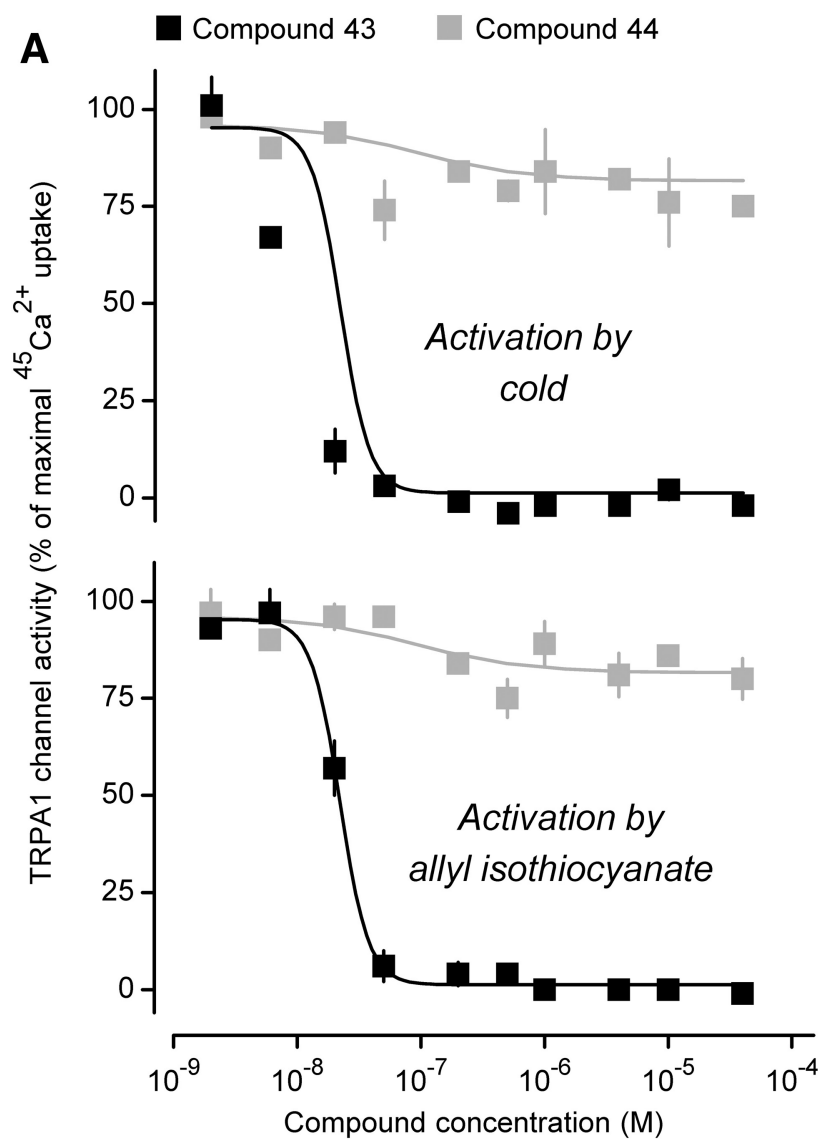

\section{B}

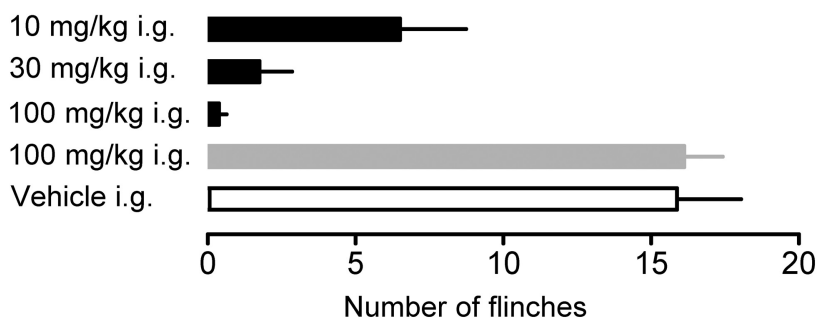

Figure 2. Compound 43 is a potent antagonist of the rat TRPA 1 channel in vitro and in vivo. A, In Chinese hamster ovary cells expressing rat TRPA1 channel, enantiopure (right) compound 43 (but not its left enantiomer compound 44) potently blocked the increase in ${ }^{45} \mathrm{Ca}^{2+}$ uptake induced by cold $\left(4^{\circ} \mathrm{C}\right)$ or AITC $(80 \mu \mathrm{m})$. For each compound-stimulus combination, the ${ }^{45} \mathrm{Ca}^{2+}$ uptake was measured twice. $\boldsymbol{B}$, Compound 43 (but not compound 44 ) attenuated the nocifensive response of rats to intraplantar administration of AITC $(0.01 \%, 25 \mu \mathrm{l})$. For each group, $n=8$.

$19.2 \pm 13.0 \mathrm{~nm}$ ), whereas compound 44 produced only partial and inconsistent effects, if any (Fig. 2A). Similar results were obtained by Gijsen et al. (2012), who studied the effects of compounds 43 and 44 on the activation of rat and human TRPA1 by a different chemical agonist (but not by cold). Our data show that effects of compound 43 on both chemical and cold activation of TRPA1 are highly sensitive to the molecule's chirality. In our selectivity assay (Lehto et al., 2008), compound 43 did not inhibit any rat or human TRP channel (other than TRPA1) at $20 \mu \mathrm{M}$. In vivo, the intragastric administration of compound 43 reduced the number of AITC-induced paw flinches in rats in a dosedependent fashion: by $59 \pm 14 \%$ at $10 \mathrm{mg} / \mathrm{kg}, 89 \pm 7 \%$ at 30 $\mathrm{mg} / \mathrm{kg}$, and $98 \pm 2 \%$ at $100 \mathrm{mg} / \mathrm{kg}$. For the ANOVA, we report $F_{(4,35)}=22.3$ and $p=3.2 \times 10^{-9}$; post hoc Dunnett's tests showed that each dosing group exhibited less finching than the vehicle group $\left(p<5.0 \times 10^{2}\right.$ for all doses). In the same test, compound
44 administered at a high dose $(100 \mathrm{mg} / \mathrm{kg})$ showed no target coverage (Fig. $2 B$ ). The demonstrated dependence of the analgesic effect of compound 43 on chirality agrees with the on-target action. We conclude that compound 43 is a highly potent, selective, and bioavailable TRPA1 antagonist that shows analgesic efficacy following gastric administration in rats.

\section{Experiment 3: pharmacological blockade of TRPA1 does not attenuate cold defenses}

Next, we studied the effect of A967079 (30 mg/kg, i.g.), compound 43 (30 mg/kg, i.g.), or their vehicle on the thermoregulatory response of rats to cold exposure. The analgesic efficacy of either TRPA1 antagonist at the dose chosen has been demonstrated in the recent study by Chen et al. (2011) (A967079) and in Experiment 2 (compound 43). Knowing that the thermoregulatory response to cold is attenuated by pharmacological blockade of the TRPM8 channel (Knowlton et al., 2011; Almeida et al., 2012; Gavva et al., 2012), we used AMG2850 (30 mg/kg, i.g.), a selective and potent TRPM8 antagonist (Gavva et al., 2012; Liu et al., 2013), as a positive control. Because rats respond to cold with cutaneous vasoconstriction and a drastic reduction in cutaneous blood flow, there was a concern that any compound administered to cold-exposed rats might not reach its targets in the skin. As in the past (Almeida et al., 2012), we dealt with this concern by using two environmental chambers. Drugs were administered to rats in the first (warm) chamber set to a $T_{a}$ of $30^{\circ} \mathrm{C}$ (the upper end of thermoneutrality in this setup). At this $T_{a}$, the skin is vasodilated (Romanovsky et al., 2002). After rats were left in the warm chamber for $30 \mathrm{~min}$, thus allowing the administered compound to circulate through the skin, they were transferred to the second chamber, which was either cold (set to a very low $T_{a}$ of $3^{\circ} \mathrm{C}$ ) or warm $\left(30^{\circ} \mathrm{C}\right.$, control). When the rats were transferred from $30^{\circ} \mathrm{C}$ to $30^{\circ} \mathrm{C}$, no significant dynamics in the parameters studied were observed, and there were no significant differences between the treatment groups in either deep $T_{b}$ or tail $T_{s k}$ (Fig. $3 A$ ). These results confirm the earlier findings that TRPM8 (Almeida et al., 2012) and TRPA1 (Chen et al., 2011) antagonists did not affect thermoregulation at thermoneutrality.

When rats were transferred from $30^{\circ} \mathrm{C}$ to $3^{\circ} \mathrm{C}$, different thermoregulatory responses occurred in different treatment groups. Vehicle-treated rats produced a small transient rise in deep $T_{b}$ followed by a gradual, mild $\left(\sim 0.9^{\circ} \mathrm{C}\right)$ decrease (Fig. $\left.3 B\right)$. This is not a surprise, as rats defend their deep $T_{b}$ against cold much better than mice (Fig. 1A) and often respond to cold exposure with an initial rise in deep $T_{b}$ (Szekely et al., 2001). The vehicletreated rats in our experiment developed rapid cutaneous vasoconstriction, and their tail $T_{s k}$ dropped to $\sim 4^{\circ} \mathrm{C}$ within minutes and remained at this level throughout the experiment. Responses of rats treated with A967079 or compound 43 did not differ statistically from those of vehicle-treated rats (Fig. $3 B$ ). In contrast, rats treated with AMG2850 showed a marked decrease in $T_{b}$ $\left(-1.8^{\circ} \mathrm{C}\right.$, nadir) in response to cold exposure. The ANOVA showed that the effects of both treatment $\left(F_{(3,594)}=216.1, p<\right.$ $\left.1.0 \times 10^{-17}\right)$ and time $\left(F_{(21,594)}=29.1, p<1.0 \times 10^{-17}\right)$ were significant, and so was the treatment $\times$ time interaction $\left(F_{(63,594)}=\right.$ $\left.1.9, p=8.1 \times 10^{-5}\right)$. According to Tukey's honestly significant difference tests, the $T_{b}$ response to AMG2850 differed significantly from the response to A967079, compound 43, or their vehicle $\left(p<7.7 \times 10^{-6}\right)$. The significant decrease in $T_{b}$ was observed during 60-180 $\min \left(p=3.1 \times 10^{-2}\right)$. The $T_{b}$ decrease in AMG2850-treated rats was presumably the result of suppression of the thermogenic response, which would also explain the disappearance of the initial $T_{b}$ rise during cold exposure in these rats (Fig. 

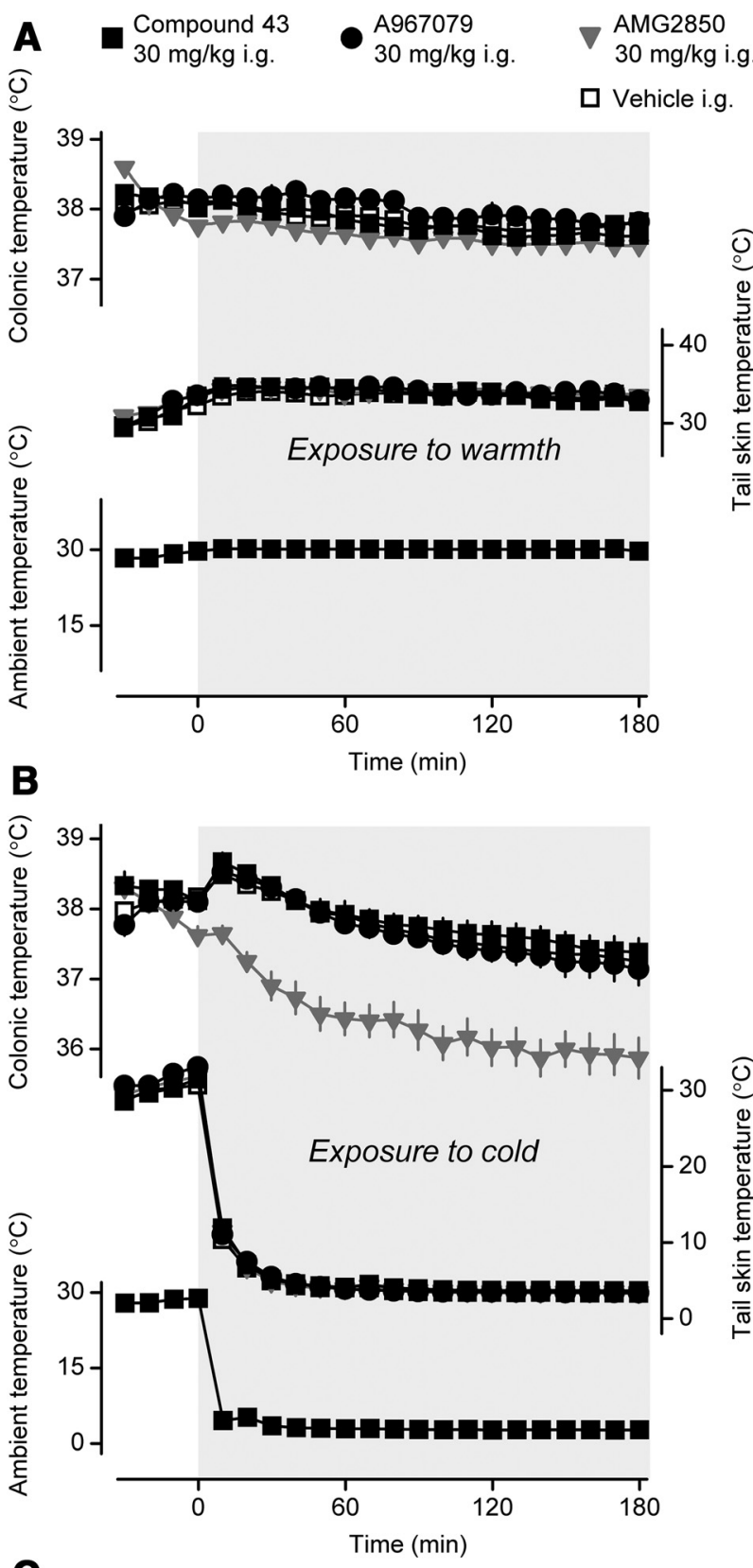

C

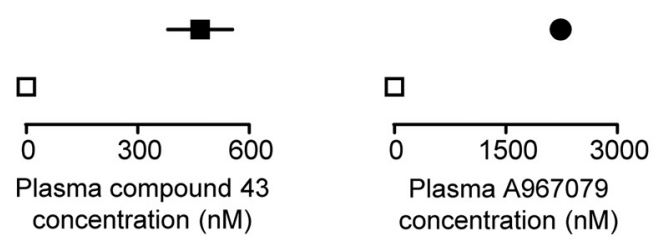

Figure 3. Pharmacological blockade of TRPA1 does not affect autonomic cold defenses in rats. $\boldsymbol{A}$, Compared with their vehicle $(n=6)$, neither the TRPA1 antagonists compound $43(n=13)$ and A967079 $(n=5)$ nor the TRPM8 antagonist AMG2850 $(n=13)$ affected the dynamics of deep $T_{b}$ or tail $T_{s k}$ in rats in the warmth. At time 0 , the rats were transferred from one environmental chamber set to $30^{\circ} \mathrm{C}$ to a second chamber, which was also set to $30^{\circ} \mathrm{C}$ (see Materials and Methods). All compounds were administered at the same dose (30 mg/kg, i.g.) $30 \mathrm{~min}$ before switching the chambers. $\boldsymbol{B}$, Compared with their vehicle $(n=11)$, the TRPA1 antagonists compound $43(n=6)$ and A967079 $(n=8)$, but not the TRPM8 antagonist AMG2850 $(n=6)$, had no effect on either the deep $T_{b}$ response to cold or cold-induced vasoconstriction (a decrease in the tail $T_{\text {sk }}$ ). At time 0 , the rats were transferred from $30^{\circ} \mathrm{C}$ to $3^{\circ} \mathrm{C}$. All compounds were administered at the same dose ( $30 \mathrm{mg} / \mathrm{kg}, \mathrm{i} . \mathrm{g}$.) 30 min before the transfer. C, Rats treated with compound 43 or A967079, but not with their vehicle, had a high concentration of the respective compound in their blood plasma at $3.5 \mathrm{~h}$ after compound administration. $B, C$, Results were obtained from the same rats.
$3 B)$. The observed suppression of the rats' ability to defend their $T_{b}$ in the cold in the presence of AMG2850 is in agreement with the reported effects of this and other TRPM8 antagonists on deep $T_{b}$ (Knowlton et al., 2010; Almeida et al., 2012; Gavva et al., 2012), oxygen consumption (Almeida et al., 2012), and brown adipose tissue temperature (Almeida et al., 2012) of cold-exposed rats and mice. In view of the negative results with both TRPA1 antagonists tested (Fig. $3 A, B$ ), it was important to confirm that their systemic levels were sufficient to block a TRPA1-dependent response. At the end of experiments, the plasma concentration of A967079 was $2.2 \pm 0.5 \mu \mathrm{M}$ in A967079-treated rats and $0.0 \pm 0.0 \mu \mathrm{M}$ in vehicle-treated controls $\left(t_{(16)}=5.5, p=4.4 \times 10^{-5}\right.$; Figure $\left.3 C\right)$. The concentration of compound 43 was $468 \pm 86 \mathrm{nM}$ in compound 43-treated rats and $0.0 \pm 0.0 \mathrm{nM}$ in vehicle-treated controls $\left(t_{(14)}=7.2, p=4.8 \times 10^{-6}\right.$; Figure $\left.3 C\right)$. Importantly, the blood levels of A967079 and compound 43 at the end of experiments were $\sim 7$ and 24 times higher, respectively, than their corresponding $\mathrm{IC}_{50}$ values. These strong exposure data agree with the reported analgesic efficacy of both compounds at the doses used in this study (Chen et al., 2011 and Experiment 2). In summary, neither of the two potent and selective TRPA1 antagonists tested affected the thermoregulatory response of rats to severe cold.

\section{Discussion}

The present study has produced two main findings. First, by using knock-out mice, we showed that the deletion of Trpal affected neither the defense of deep $T_{b}$ against cold nor the coldinduced activation of autonomic thermoeffectors (tail skin vasoconstriction and thermogenesis). The severity of the cold exposure in this experiment (deep $T_{b}$ was $\sim 13^{\circ} \mathrm{C}$ by the end of experiment) was probably sufficient to bring all temperatures in the body below the threshold temperature for TRPA1 activation, even if the in vivo threshold differs by a couple of degrees from the $17^{\circ} \mathrm{C}$ threshold reported in vitro (Story et al., 2003). This suggests that murine TRPA1 channels do not drive autonomic colddefense effectors. However, our study in knock-out mice did not address the issue of potential structural or functional compensation for the chronic lack of TRPA1 in genetically modified animals. To avoid any such compensation, we used the acute administration of pharmacological TRPA1 antagonists, either compound 43 or A967079, in genetically unaltered rats, and our second main finding was obtained in experiments with these antagonists.

In a paradigm where any chronic compensation was not a concern, we showed that neither compound 43 nor A967079 affected the $T_{b}$ response of rats to cold exposure. This suggests that the thermoregulation system does not use TRPA1dependent temperature signals, at least not in the rat. To make this conclusion definitive, we took multiple methodological precautions and ruled out several alternative interpretations. First, we used two chemically unrelated TRPA1 antagonists (one of which, compound 43, was also characterized in the present study). Second, the dose selected for either antagonist $(30 \mathrm{mg} / \mathrm{kg}$, i.g.) has been demonstrated to be efficacious in blocking TRPA1dependent pain responses in the same species (Chen et al., 2011; present study). Third, because of cutaneous vasoconstriction in the cold, compounds that are normally efficacious may not reach their targets in the skin during cold exposure (Almeida et al., 2012). To avoid this pitfall, we administered TRPA1 antagonists in a warm environment, in which cutaneous vasodilation was present and confirmed by a high $T_{s k}$. Only after the compounds were allowed to circulate through the skin for $30 \mathrm{~min}$ were the 
animals exposed to the cold. Fourth, we also directly measured both compounds in blood plasma and found that, even at the end of the experiment, each TRPA1 antagonist was still present at a concentration that exceeded its $\mathrm{IC}_{50}$ value by an order of magnitude. Fifth, we monitored the $T_{s k}$ and confirmed that, at least in the tail, it was substantially (by $\sim 13^{\circ} \mathrm{C}$ ) below the $17^{\circ} \mathrm{C}$ threshold temperature for TRPA1 activation throughout the experiment. Last but not least, we have demonstrated that our methodological design was adequate to reveal a deficit in the detection of cutaneous temperature signals used by the thermoregulation system. When we blocked TRPM8 channels, cold-sensitive channels (for review, see Latorre et al., 2011) that function as sensors of skin temperature signals driving autonomic and behavioral thermoeffectors (Almeida et al., 2012), with AMG2850, an efficacious TRPM8 antagonist (Gavva et al., 2012; Liu et al., 2013), rats were unable to maintain their deep $T_{b}$ in the cold in our setup. Hence, our conclusion that shell temperature sensors that serve thermoregulation in rodents do not include TRPA1 has strong grounds.

One can still argue that deep $T_{b}$ in our experiments with TRPA1 antagonists did not reach the threshold level for TRPA1 activation and that our experiments do not rule out the possibility that TRPA 1 channels serve as core $T_{b}$ sensors for the thermoregulation system, as proposed by Fajardo et al. (2008). Although we did not test this hypothesis in the experiment with pharmacological blockade of TRPA1 in rats, our experiments with genetic deletion of Trpal in mice (in which deep $T_{b}$ was below the TRPA1 activation threshold) argue against it. Furthermore, peripheral thermosensors (that are predominantly cold sensors) are well known to be more important for cold defenses than central sensors (that are predominantly warmth sensors) (for review, see Romanovsky, 2007, in press). Such organization makes sense, as a brief look at Figure $3 B$ shows that the very severe cold exposure $\left(3^{\circ} \mathrm{C}\right)$ in rats resulted only in a small change in deep $T_{b}$ (tenths of a degree), but in a large change in $T_{s k}$ (tens of degrees) - it would be logical to locate cold sensors in the skin. Furthermore, except for special cases (e.g., small animals that readily develop torpor), values of deep $T_{b}$ below the TRPAl activation threshold are highly unusual for mammals. But even if there were a central cold sensor for such unusual situations, it probably would not be a TRP channel, as electrophysiological effects of temperature on hypothalamic neurons seem incompatible with mediation by TRP channels (Boulant, 2006). Indeed, several studies have found no difference between temperature-sensitive and insensitive neurons in terms of temperature's effect on resting membrane potentials and currents (Griffin and Boulant, 1995; Zhao and Boulant, 2005).

A shortcoming of Experiments 1 and 3 was that tail vasoconstriction was assessed by a $T_{s k}$ decrease, which can reflect not only a decrease in the blood flow but also a $T_{a}$ decrease (skin cooling by conduction and convection) or a decrease in the deep $T_{b}$ (and, consequently, in the temperature of arterial blood entering the tail). When $T_{a}$ is constant, the passive cooling effect can be alleviated by calculating the heat loss index (for details, see Romanovsky et al., 2002). This was not an option in our experiments, in which a deep cold exposure was introduced rapidly. Under these conditions, the vasoconstriction-related portion of the overall decrease in $T_{s k}$ could be hard to reveal (e.g., see Almeida et al., 2012), and our conclusions about tail vasoconstriction should be taken with a grain of salt. For example, the lack of effect of AMG2850 on the cold-induced vasoconstriction (Fig. 3 ) is in disagreement with the detectable (although small) effect of another TRPM8 antagonist, M8-B, in our earlier study (Almeida et al., 2012).
It is clear that TRPA1 channels are involved in nocifensive responses to chemical irritants (Nilius et al., 2012), and our present data, both in vitro and in vivo, support such an involvement. In vitro, we showed that compound 43 blocked AITC-induced activation of rat TRPA1; in vivo, we showed that the same TRPA1 antagonist blocked the pain response of rats to AITC, and also that deletion of the Trpal gene in mice attenuated the pain response to mustard oil. There is, however, no consensus as to whether rodent TRPA1 channels serve as cold sensors for nocifensive responses, and, in general, whether TRPA1 channels are (Story et al., 2003; Viswanath et al., 2003; Bandell et al., 2004; Kwan et al., 2006, 2009; Klionsky et al., 2007; Fajardo et al., 2008; Andersson et al., 2009; Karashima et al., 2009; del Camino et al., 2010) or are not (Jordt et al., 2004; Nagata et al., 2005; Bautista et al., 2006, 2007; Knowlton et al., 2010; del Camino et al., 2010; Chen et al., 2011; Cordero-Morales et al., 2011) activated by temperature. Doerner et al. (2007) have shown that $\mathrm{Ca}^{2+}$ may directly gate the TRPA1 channel, and Zurborg et al. (2007) proposed that cold activation of TRPA1 is indirect and nonphysiological, and that it occurs in heterologous systems through the increased $\mathrm{Ca}^{2+}$ influx. In defense of the possibility of direct activation by cold, Sawada et al. (2007) performed inside-out singlechannel recordings under $\mathrm{Ca}^{2+}$-chelating conditions and observed direct activation of TRPA1 by low temperatures. At least two other groups reported cold activation of TRPA1 in $\mathrm{Ca}^{2+}$-free media (Karashima et al., 2009; del Camino et al., 2010). Furthermore, at least in insects, there are several isoforms of TRPA1, some of which are thermosensitive (warmthsensitive), whereas others are not (Kang et al., 2011; Zhong et al., 2012). For example, antennal TRPA1 channels in fruit flies do not play any significant role in the detection of warmth (Gallio et al., 2011). Zebrafish TRPA1 channels also do not possess a thermosensory function (Prober et al., 2008).

Even among the mammalian TRPA1 proteins, species differences may further complicate the issue (Chen and Kym, 2009). For example, heterologously expressed mouse TRPA1 may be activated by noxious cold (Story et al., 2003; Sawada et al., 2007; Karashima et al., 2009), whereas human TRPA1 is not (Jordt et al., 2004). Our study does not shed light on what makes some TRPA1 proteins highly sensitive to temperature. In our in vitro experiments, rat TRPA1 channels in Chinese hamster ovary cells were activated by cold, but whether the observed activation was direct or indirect is unknown.

Even if rat or mouse TRPA1 channel is activated by cold and mediates cold pain, it is still not involved in thermoregulation. From this point of view, the TRPA1 channel is similar to the vanilloid channel TRPV1, which is highly sensitive to temperature, mediates pain responses to noxious heat, but is not involved as a thermosensor in $T_{b}$ regulation, at least not under usual conditions (for review, see Romanovsky et al., 2009). TRPV1 and TRPA1 are coexpressed on polymodal nociceptors (Julius, 2013), which are probably not involved in the reception of temperature signals that drive autonomic and behavioral thermoeffectors.

In conclusion, our experiments in mice and rats show that either TRPA1 channels are not activated by cold in vivo, or that they are expressed on cells that are not wired to convey signals to autonomic thermoeffectors, or both. In either scenario, TRPA1 channels in rodents are not used as thermosensors by the thermoregulation system, even during an exposure to severe cold.

\section{References}

Almeida MC, Hew-Butler T, Soriano RN, Rao S, Wang W, Wang J, Tamayo N, Oliveira DL, Nucci TB, Aryal P, Garami A, Bautista D, Gavva NR, 
Romanovsky AA (2012) Pharmacological blockade of the cold receptor TRPM8 attenuates autonomic and behavioral cold defenses and decreases deep body temperature. J Neurosci 32:2086-2099. CrossRef Medline

Andersson DA, Gentry C, Moss S, Bevan S (2009) Clioquinol and pyrithione activate TRPAl by increasing intracellular $\mathrm{Zn}^{2+}$. Proc Natl Acad Sci U S A 106:8374-8379. CrossRef Medline

Bandell M, Story GM, Hwang SW, Viswanath V, Eid SR, Petrus MJ, Earley TJ, Patapoutian A (2004) Noxious cold ion channel TRPAl is activated by pungent compounds and bradykinin. Neuron 41:849-857. CrossRef Medline

Bang S, Hwang SW (2009) Polymodal ligand sensitivity of TRPA1 and its modes of interactions. J Gen Physiol 133:257-262. CrossRef Medline

Bautista DM, Jordt SE, Nikai T, Tsuruda PR, Read AJ, Poblete J, Yamoah EN, Basbaum AI, Julius D (2006) TRPA1 mediates the inflammatory actions of environmental irritants and proalgesic agents. Cell 124:1269-1282. CrossRef Medline

Bautista DM, Siemens J, Glazer JM, Tsuruda PR, Basbaum AI, Stucky CL, Jordt SE, Julius D (2007) The menthol receptor TRPM8 is the principal detector of environmental cold. Nature 448:204-208. CrossRef Medline

Boulant JA (2006) Counterpoint. Heat-induced membrane depolarization of hypothalamic neurons: an unlikely mechanism of central thermosensitivity. Am J Physiol 290:R1481-R1484. Medline

Caspani O, Heppenstall PA (2009) TRPA1 and cold transduction: an unresolved issue? J Gen Physiol 133:245-249. CrossRef Medline

Chen J, Kym PR (2009) TRPA1: the species difference. J Gen Physiol 133: 623-625. CrossRef Medline

Chen J, Joshi SK, DiDomenico S, Perner RJ, Mikusa JP, Gauvin DM, Segreti JA, Han P, Zhang XF, Niforatos W, Bianchi BR, Baker SJ, Zhong C, Simler GH, McDonald HA, Schmidt RG, McGaraughty SP, Chu KL, Faltynek CR, Kort ME, et al. (2011) Selective blockade of TRPAl channel attenuates pathological pain without altering noxious cold sensation or body temperature regulation. Pain 152:1165-1172. CrossRef Medline

Cordero-Morales JF, Gracheva EO, Julius D (2011) Cytoplasmic ankyrin repeats of transient receptor potential A1 (TRPA1) dictate sensitivity to thermal and chemical stimuli. Proc Natl Acad Sci U S A 108:E1184E1191. CrossRef Medline

Davis KD, Pope GE (2002) Noxious cold evokes multiple sensations with distinct time courses. Pain 98:179-185. CrossRef Medline

del Camino D, Murphy S, Heiry M, Barrett LB, Earley TJ, Cook CA, Petrus MJ, Zhao M, D'Amours M, Deering N, Brenner GJ, Costigan M, Hayward NJ, Chong JA, Fanger CM, Woolf CJ, Patapoutian A, Moran MM (2010) TRPA1 contributes to cold hypersensitivity. J Neurosci 30:15165-15174. CrossRef Medline

Doerner JF, Gisselmann G, Hatt H, Wetzel CH (2007) Transient receptor potential channel $\mathrm{Al}$ is directly gated by calcium ions. J Biol Chem 282: 13180-13189. CrossRef Medline

Fajardo O, Meseguer V, Belmonte C, Viana F (2008) TRPAl channels mediate cold temperature sensing in mammalian vagal sensory neurons: pharmacological and genetic evidence. J Neurosci 28:7863-7875. CrossRef Medline

Gallio M, Ofstad TA, Macpherson LJ, Wang JW, Zuker CS (2011) The coding of temperature in the Drosophila brain. Cell 144:614-624. CrossRef Medline

Garami A, Pakai E, Oliveira DL, Steiner AA, Wanner SP, Almeida MC, Lesnikov VA, Gavva NR, Romanovsky AA (2011) Thermoregulatory phenotype of the Trpv1 knock-out mouse: thermoeffector dysbalance with hyperkinesis. J Neurosci 31:1721-1733. CrossRef Medline

Gavva NR, Davis C, Lehto SG, Rao S, Wang W, Zhu DX (2012) Transient receptor potential melastatin 8 (TRPM8) channels are involved in body temperature regulation. Mol Pain 8:36. CrossRef Medline

Gijsen HJ, Berthelot D, De Cleyn MA, Geuens I, Brône B, Mercken M (2012) Tricyclic 3,4-dihydropyrimidine-2-thione derivatives as potent TRPA1 antagonists. Bioorg Med Chem Lett 22:797-800. CrossRef Medline

Gracheva EO, Ingolia NT, Kelly YM, Cordero-Morales JF, Hollopeter G, Chesler AT, Sánchez EE, Perez JC, Weissman JS, Julius D (2010) Molecular basis of infrared detection by snakes. Nature 464:1006-1011. CrossRef Medline

Griffin JD, Boulant JA (1995) Temperature effects on membrane potential and input resistance in rat hypothalamic neurones. J Physiol 488:407418. Medline

Hamada FN, Rosenzweig M, Kang K, Pulver SR, Ghezzi A, Jegla TJ, Garrity PA (2008) An internal thermal sensor controlling temperature preference in Drosophila. Nature 454:217-220. CrossRef Medline

Jordt SE, Bautista DM, Chuang HH, McKemy DD, Zygmunt PM, Högestätt
ED, Meng ID, Julius D (2004) Mustard oils and cannabinoids excite sensory nerve fibres through the TRP channel ANKTM1. Nature 427: 260-265. CrossRef Medline

Julius D (2013) TRP channels and pain. Annu Rev Cell Dev Biol 29:355384. CrossRef Medline

Kang K, Panzano VC, Chang EC, Ni L, Dainis AM, Jenkins AM, Regna K, Muskavitch MA, Garrity PA (2011) Modulation of TRPA1 thermal sensitivity enables sensory discrimination in Drosophila. Nature 481:76-80. CrossRef Medline

Karashima Y, Talavera K, Everaerts W, Janssens A, Kwan KY, Vennekens R, Nilius B, Voets T (2009) TRPA1 acts as a cold sensor in vitro and in vivo. Proc Natl Acad Sci U S A 106:1273-1278. CrossRef Medline

Klionsky L, Tamir R, Gao B, Wang W, Immke DC, Nishimura N, Gavva NR (2007) Species-specific pharmacology of trichloro(sulfanyl)ethyl benzamides as transient receptor potential ankyrin 1 (TRPA1) antagonists. Mol Pain 3:39. CrossRef Medline

Knowlton WM, Bifolck-Fisher A, Bautista DM, McKemy DD (2010) TRPM8, but not TRPA1, is required for neural and behavioral responses to acute noxious cold temperatures and cold-mimetics in vivo. Pain 150: 340-350. CrossRef Medline

Knowlton WM, Daniels RL, Palkar R, McCoy DD, McKemy DD (2011) Pharmacological blockade of TRPM8 ion channels alters cold and cold pain responses in mice. PLoS One 6:e25894. CrossRef Medline

Kwan KY, Corey DP (2009) Burning cold: involvement of TRPA1 in noxious cold sensation. J Gen Physiol 133:251-256. CrossRef Medline

Kwan KY, Allchorne AJ, Vollrath MA, Christensen AP, Zhang DS, Woolf CJ, Corey DP (2006) TRPA1 contributes to cold, mechanical, and chemical nociception but is not essential for hair-cell transduction. Neuron 50 : 277-289. CrossRef Medline

Kwan KY, Glazer JM, Corey DP, Rice FL, Stucky CL (2009) TRPA1 modulates mechanotransduction in cutaneous sensory neurons. J Neurosci 29: 4808-4819. CrossRef Medline

Kwon Y, Shim HS, Wang X, Montell C (2008) Control of thermotactic behavior via coupling of a TRP channel to a phospholipase $\mathrm{C}$ signaling cascade. Nat Neurosci 11:871-873. CrossRef Medline

Latorre R, Brauchi S, Madrid R, Orio P (2011) A cool channel in cold transduction. Physiology (Bethesda) 26:273-285. CrossRef Medline

Lehto SG, Tamir R, Deng H, Klionsky L, Kuang R, Le A, Lee D, Louis JC, Magal E, Manning BH, Rubino J, Surapaneni S, Tamayo N, Wang T, Wang J, Wang J, Wang W, Youngblood B, Zhang M, Zhu D, et al. (2008) Antihyperalgesic effects of $(R, E)-N$-(2-hydroxy-2,3-dihydro-1 $H$-inden-4-yl)-3-(2-(piperidin1-yl)-4-(trifluoromethyl)phenyl)-acrylamide (AMG8562), a novel transient receptor potential vanilloid type 1 modulator that does not cause hyperthermia in rats. J Pharmacol Exp Ther 326:218-229. CrossRef Medline

Liu B, Fan L, Balakrishna S, Sui A, Morris JB, Jordt SE (2013) TRPM8 is the principal mediator of menthol-induced analgesia of acute and inflammatory pain. Pain 154:2169-2177. CrossRef Medline

Nagata K, Duggan A, Kumar G, García-Añoveros J (2005) Nociceptor and hair cell transducer properties of TRPA1, a channel for pain and hearing. J Neurosci 25:4052-4061. CrossRef Medline

Nilius B, Appendino G, Owsianik G (2012) The transient receptor potential channel TRPA1: from gene to pathophysiology. Pflugers Arch 464:425458. CrossRef Medline

Prober DA, Zimmerman S, Myers BR, McDermott BM Jr, Kim SH, Caron S, Rihel J, Solnica-Krezel L, Julius D, Hudspeth AJ, Schier AF (2008) Zebrafish TRPA1 channels are required for chemosensation but not for thermosensation or mechanosensory hair cell function. J Neurosci 28: 10102-10110. CrossRef Medline

Romanovsky AA (2007) Thermoregulation: some concepts have changed. Functional architecture of the thermoregulatory system. Am J Physiol 292:R37-R46. CrossRef Medline

Romanovsky AA (2014) Skin temperature: its role in thermoregulation. Acta Physiol 210:498-507. CrossRef

Romanovsky AA, Ivanov AI, Shimansky YP (2002) Selected contribution. Ambient temperature for experiments in rats: a new method for determining the zone of thermal neutrality. J Appl Physiol 92:2667-2679. CrossRef Medline

Romanovsky AA, Almeida MC, Garami A, Steiner AA, Norman MH, Morrison SF, Nakamura K, Burmeister JJ, Nucci TB (2009) The transient receptor potential vanilloid- 1 channel in thermoregulation: a thermosensor it is not. Pharmacol Rev 61:228-261. CrossRef Medline 
Sawada Y, Hosokawa H, Hori A, Matsumura K, Kobayashi S (2007) Cold sensitivity of recombinant TRPAl channels. Brain Res 1160:39-46. CrossRef Medline

Steiner AA, Turek VF, Almeida MC, Burmeister JJ, Oliveira DL, Roberts JL, Bannon AW, Norman MH, Louis JC, Treanor JJ, Gavva NR, Romanovsky AA (2007) Nonthermal activation of transient receptor potential vanilloid- 1 channels in abdominal viscera tonically inhibits autonomic cold-defense effectors. J Neurosci 27:7459-7468. CrossRef Medline

Steiner AA, Molchanova AY, Dogan MD, Patel S, Pétervári E, Balaskó M, Wanner SP, Eales J, Oliveira DL, Gavva NR, Almeida MC, Székely M, Romanovsky AA (2011) The hypothermic response to bacterial lipopolysaccharide critically depends on brain CB1, but not CB2 or TRPV1, receptors. J Physiol 589:2415-2431. CrossRef Medline

Story GM, Peier AM, Reeve AJ, Eid SR, Mosbacher J, Hricik TR, Earley TJ, Hergarden AC, Andersson DA, Hwang SW, McIntyre P, Jegla T, Bevan S, Patapoutian A (2003) ANKTM1, a TRP-like channel expressed in noci- ceptive neurons, is activated by cold temperatures. Cell 112:819-829. CrossRef Medline

Szekely M, Szelenyi Z, Petervari E, Balasko M (2001) Thermoregulatory “overshoot" reactions in cold-adapted rats. J Therm Biol 26:491-497. CrossRef

Viswanath V, Story GM, Peier AM, Petrus MJ, Lee VM, Hwang SW, Patapoutian A, Jegla T (2003) Opposite thermosensor in fruitfly and mouse. Nature 423:822-823. CrossRef Medline

Zhao Y, Boulant JA (2005) Temperature effects on neuronal membrane potentials and inward currents in rat hypothalamic tissue slices. J Physiol 564:245-257. CrossRef Medline

Zhong L, Bellemer A, Yan H, Ken H, Jessica R, Hwang RY, Pitt GS, Tracey WD (2012) Thermosensory and nonthermosensory isoforms of Drosophila melanogaster TRPA1 reveal heat-sensor domains of a thermoTRP channel. Cell Rep 1:43-55. CrossRef Medline

Zurborg S, Yurgionas B, Jira JA, Caspani O, Heppenstall PA (2007) Direct activation of the ion channel TRPA1 by $\mathrm{Ca}^{2+}$. Nat Neurosci 10:277-279. CrossRef Medline 